\title{
Industrial enzymes in bioindustrial sector development: An Indian perspective
}

Anuj Kumar Chandel, Ravinder Rudravaram, Linga Venkateswar Rao, Pogaku Ravindra and Mangamoori Lakshmi Narasu

Date Received (in revised form): 2nd August, 2007

\begin{abstract}
Anuj Kumar Chandel
has an MSc and is currently pursuing a PhD in biotechnology at the Jawaharlal Nehru Technological University. He is also working with Celestial Labs Ltd, Hyderabad, as a project consultant in establishing the enzymes production facility. He previously worked for Dalas Biotech Ltd, Bhiwadi, India, in the production of Penicillin G acylase and beta-lactam antibiotics and on bioethanol production from lignocellulosics under a nationwide research project funded by Department of Biotechnology (DBT, Ministry of Science and Technology, Govt. of India). He is an author of ten articles in peer-reviewed journals and books.
\end{abstract}

\section{Ravinder Rudravaram}

has an MSc in biotechnology and a PhD in microbiology. Previously, he was a manager for R\&D at Prathistha Biotech Ltd, Hyderabad, and is currently with Celestial Labs Ltd, Hyderabad, as a Senior Manager of Biotech Projects. He recently finished a research project on cloning of the vitiligo gene at Center of Cellular and Molecular Biology (CCMB), Hyderabad. He is the author of ten articles in peer-reviewed journals.

\begin{abstract}
Linga Venkateswar Rao
holds an MSc and a PhD in microbiology. He is Professor and Chairman of the Board of Studies at Osmania University, Hyderabad, India. He has 35 years of teaching, research, administration and industrial experience and has been honorary consultant to many industrial biotech companies in India. His area of specialisation is industrial microbiology and has 55 national and international publications to his credit.
\end{abstract}

\section{Pogaku Ravindra}

holds an MTech in chemical engineering and a PhD in biotechnology and is a faculty member of Chemical Engineering at the University of Sabah, Malaysia. He was a visiting scientist at Cornell University, USA. He has 25 years of teaching, research, administration and industrial experience and has been an honorary consultant to many food and biotech companies. He has published and presented over 150 papers, ten keynote and plenary lectures in the USA, UK, Canada, India and Malaysia.

\section{Mangamoori Lakshmi Narasu}

has an MSc and PhD in microbiology. She is Professor and Head at the Centre for Biotechnology, Jawaharlal Nehru Technological University, Hyderabad, India. She has 30 years of teaching, research and administration experience and has been honorary consultant to many biotech companies in India. Her area of specialisation is microbial biotechnology and has 55 national and international publications to her credit.

\begin{abstract}
The bioindustrial and information technology sectors have been the two most-decisive factors for the rising Indian economy over the last 15 years. India is the second fastest growing economy in the world, with a gross domestic product (GDP) of 9.2 per cent in 2006-2007. Industrial enzymes production and marketing predominantly cover the developments incurred in the bioindustrial sector. In 2006-2007, the bioindustrial sector made an impressive turnover of Rs. $3950 \mathrm{~m}$, with a growth rate of 5.33 per cent. India imports about 70 per cent of the total enzyme consumption. Pharmaceutical enzymes are the representatives of industrial enzymes' demand in India and cover almost 50 per cent of the total enzyme demand, followed by detergent enzymes ( 20 per cent) and textile enzymes ( 20 per cent). The global market for enzymes was estimated to be about $\$ 2 \mathrm{bn}$ in 2004 in tune with an average
\end{abstract}

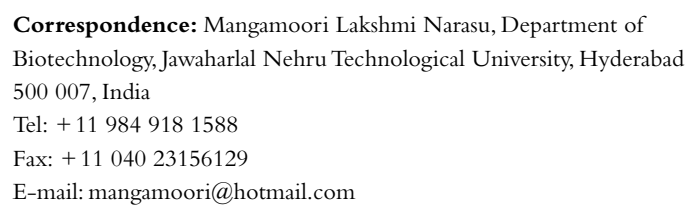


annual growth rate of 3.3 per cent. This article touches upon the importance of major industrial enzymes in the development of the bioindustrial sector in India. Also, applications of enzymes, manufacturing industries and major suppliers or distributors of enzymes have been discussed. Journal of Commercial Biotechnology (2007) 13, 283-291. doi:10.1057/palgrave.jcb.3050065

Keywords: bioindustrial, enzyme industries, industrial enzymes, India

\section{INTRODUCTION}

The Indian economy since 1990 has risen sharply. Today, the economy of India is the third largest in the world as measured by purchasing power parity (PPP) with a GDP (gross domestic product) of US $\$ 1.0$ trillion upon measuring in USD exchange rate terms. ${ }^{1}$ India is the second fastest growing major economy in the world after China, with a GDP growth rate of 9.2 per cent at the end of the second quarter of 2006-2007. ${ }^{2}$ The main driving forces behind this unprecedented success are information technology (IT) and biotechnology (BT). ${ }^{3}$ IT and BT constitute approximately 5 per cent of the country's GDP, showing 23 and 40 per cent growth, respectively, during the year 1999-2000. BT covers a very broad range of specialised areas including biopharmaceutical, bioindustrial, bioservices, bioagriculture and bioinformatics. Out of these, the bioindustrial sector, which encompasses the harnessing of microorganisms for the production of value-added bioactive ingredients (industrial enzymes, organic acids, bulk chemicals, single-cell proteins, etc.), has played a predominant role in the overall development of biotechnology after biopharmaceuticals. Both biopharmaceutical and bioindustrial industries generated almost Rs. 35,700 and 4,250m revenue during the year 2004-2005, respectively. ${ }^{4}$ Table 1 presents the breakup of revenue generated by different Indian biotechnology industries. ${ }^{3,4}$ In recent years, BT has shown a slow but steady growth and has emerged as an important contributor to world economy. According to Ernst and Young's 2005 Annual Global Biotechnology Report, the biotechnology sector is one of the fastest growing sectors, with a revenue growth of 17 per cent from 2003 to $2004 .^{5}$

Recent biotechnological innovations have paved the way for the successful production of various biocommodities at a commercial level that not only improved the product economics but also the environment by replacing the conventional chemical conversion routes. In the country, the role of Government-funded research institutes, universities and private sector is highly remarkable in making BT successful at a commercial level. India has emerged as a major hub for cutting-edge R\&D bioindustrial projects for global multinationals such as Novozymes (Denmark), Genencore and Dyadic International (USA) and Quest International (Irish Republic). Recently, the Danish company CHR-Hansen was launched in India for marketing the enzymes applied in food and feed products, while Novozymes recently opened its R\&D centre at Bangalore. ${ }^{6}$ These industrial giants are now aiming towards the development of potent and 'designer' cellulases for the cheap and efficient production of bioethanol, the future renewable energy source. Apart from industrial enzyme manufacturers, bioservices and biopharmaceutical companies have shown an excellent turnover in India. Table 2 shows the net turnover of the top 15 Indian BT industries during the year 2004-2005.

Worldwide, Europe has considerable assets in the field of industrial biotechnology. In Europe, 70 per cent of the world enzyme industries exist with a high level of

Table I: Total revenue generated by Indian biotechnology industries (revenue in Rs. in millions)

\begin{tabular}{lrrr}
\hline $\begin{array}{l}\text { Industrial } \\
\text { sector }\end{array}$ & 2002-2003 & 2003-2004 & 2004-2005 \\
\hline Biopharmaceuticals & 17,900 & 27,520 & 35,700 \\
Bioindustrial & 2,350 & 2,750 & 4,250 \\
Bioagriculture & 1,350 & 1,300 & 3,300 \\
Bioinformatics & 1,100 & 2,380 & 3,200 \\
Total & 23,450 & 34,750 & 47,450 \\
\hline
\end{tabular}

Source: Biospectrum, June, 2005 (www.biospectrumindia.com), Mani. $^{3}$ 
Table 2: Top fifteen BT companies in India (on the basis of total turnover in 2004-2005)

\begin{tabular}{ll}
\hline Company & $\begin{array}{l}\text { Turn over } \\
\text { (Rs. in millions) }\end{array}$ \\
\hline Biocon & 6,463 \\
Serum Institute of India & 5,650 \\
Panacea Biotec & 2,173 \\
Venkateshwara Hatcheries & 1,880 \\
Mahyco Monsanto & 1,664 \\
Novo Novardisk & 1,350 \\
Avantis Pharma & 869 \\
Rasi Seeds & 843 \\
Bharat Serums & 810 \\
Chron BehringVaccines & 780 \\
Glaxo Smithkline & 778 \\
Indian Immunologicals & 724 \\
Shanta Biotechnics & 700 \\
Novozymes & 690 \\
Eli Lilly and Company & 684 \\
\hline
\end{tabular}

Source: Mani. ${ }^{3}$

knowledge in the field of food technology and fine chemistry. ${ }^{7,8}$ Due to an everincreasing labour, energy and raw material costs, more bulk manufacturing companies are, however, moving to the Far East. In the present time of increased industrial development, the impetus of industrial biotechnology in the improvement of any nation's economy is crucial.

A recent Frost and Sullivan study depicts that various contract research models like joint research, collaborative research and complete outsourcing have given the BT sector a successful impetus worldwide. India has the 12th most successful BT industry in the world as measured by the number of companies. The main driving force for commercialisation of BT in India is the Department of Biotechnology (DBT) of the Ministry of Science and Technology. DBT played a vital role in the commercialisation of R\&D activities for biotechnology, human resource development and bioinformatics programmes and has declared a new development strategy in 2005 for revenue generation up to US $\$ 5$ bn annually and to create one million jobs by $2010 .^{3}$

Enzymes have been the centre of attention for researchers/industrialists the world over due to their wide range of physiological, analytical and industrial applications. Although enzymes have been isolated, purified and studied from microbial, animal and plant sources, microorganisms represent the most common source of enzymes due to their broad biochemical diversity and feasibility of large-level production by exploiting cheap carbohydrate sources. ${ }^{9,10}$

This review presents an overview of the current status of the bioindustrial sector in India. Particular emphasis is placed on the Indian enzyme manufactures and suppliers and enzyme applications.

\section{MAJOR INDUSTRIAL ENZYMES AND THEIR APPLICATIONS: AN APPRAISAL}

Enzymes are catalysts, organic compounds produced by living organisms that accelerate the transformation rate of substrate to the end product by lowering the activation energy barrier. ${ }^{11}$ Although all enzymes are initially produced in the cell, some are secreted through the cell wall and function in the cell's environment. Hence, we recognise two types of enzymes on the basis of site of action: intracellular enzymes or endozymes (functioning in the cell), and extracellular enzymes or exoenzymes (functioning outside the cell). ${ }^{7}$ Diastase was the first commercialised enzyme for the production of dextrins in bakeries, beer and wine from fruits in France in $1830 .{ }^{12}$ In 1874, in Denmark, Christian Hansen started the first company (Christian Hansen's Laboratory) for the marketing of standardised enzyme preparations, rennet for cheese making. ${ }^{7}$ In USA, J. Takamine isolated bacterial amylases in the 1890s at Miles Laboratories. In 1913, Otto Rohm's patent gave the idea of using pancreatic extract enzymes as washing aids for laundry cleaning and the product was marketed under the brand name Brunus and sold in European markets for about 50 years. ${ }^{13}$ In the mid-1960s, Novo Industri A/S introduced alkaline protease in the market produced by Bacillus licheniformis under the brand Alkalase. ${ }^{14}$ Furthermore, in 1985, Novo launched a new multi-enzyme preparation containing -cellulase, alkaline protease and other enzymes, which brought evolutionary changes in the market. In general, an ideal enzyme for detergent preparation should be effective at low levels (0.4-0.8 per cent) in 
the detergent solutions. Today, proteases are the leaders of the industrial enzyme market worldwide. ${ }^{13,14}$

Now enzymes have attained the status of a household commodity. Recent developments in the field of enzymology, such as genetic engineering development for recombinant enzymes, search for biodegradable carriers for immobilisation, extremozymes and recently cross-linked enzyme crystals yielding stable enzymes, are more suitable for commercial organic synthesis and their resolution. ${ }^{15}$

Modern enzyme technology, in conjunction with multidisciplinary scientific knowledge and process technology, is crucial for the development of new, clean and cost-effective manufacturing concepts for food specialty (e.g., bread, cheese, alcoholic beverages, vinegar, fruit juice, etc.), fine-chemical (e.g., amino acids, vitamins), bulk chemical commodities (bioethanol, biodiesel, xylitol, 2, 3-propanediol, etc.), and pharmaceutical and neutraceutical products. ${ }^{16,17}$ Enzymes also have an application for a wide range of analytical purposes especially in food diagnostics and as sensors in electrochemical reactions. Table 3 presents the major industrial enzymes and their broad-range applications. ${ }^{13,14,18-29}$

Global sales of industrial enzymes were valued at $\$ 2 \mathrm{bn}$ in $2004 .{ }^{29}$ The market for Pharmaceutical enzymes accounted for 41 per cent of the market with food and feed industry (17 per cent) and detergent industry (17 per cent) as shown in Figure $1 .{ }^{30} \mathrm{~A}$ recent McKinsey estimate suggests that the total value created by enzymes could be to the tune of $\$ 12 \mathrm{bn}$ a year by 2010 globally. In India, the maximum demand of enzymes is in pharmaceutical industries, followed by food/ feed and textiles (Figure 2). In India, the bioindustrial sector, which predominantly comprises the enzyme companies, is estimated to be Rs. 3,950m in 2006-2007 and registered 5.33 per cent growth in 20062007. ${ }^{4,30}$ India imports about 70 per cent of the total enzymes consumed in the country, the majority of which goes to the detergent, textile, starch and pharmaceutical industries. Based on available information, the estimated consumption of industrial enzymes in India in various sectors has been summarised in
Table 4. The pharmaceutical segment is, however, still the leader in terms of enzyme demand and captures 50 per cent of the demand. ${ }^{4}$

Enzymes have broad applications. Their application is direct in different industries - food and feed (alpha amylase, glucose isomerase, cellulase, xylanase, pectinase, phytase), detergent (alkaline protease, cellulase), pulp and paper (xylanase, laccase, cellulase, pectinase), leather tanning (tannase) and pharmaceuticals (penicillin acylases, cephalosporin acylases, glutaryl 7-ACA acylases and D-amino acid oxidases) and waste treatment (laccases, tannases). They are an indispensable source for today's human applications. ${ }^{9,10}$ Enzymes have made many biotransformation processes very easy and quick, with high reproducibility.

\section{INDIAN SCENARIO OF INDUSTRIAL ENZYMES'S PRODUCTION}

In India, the major industrial enzyme manufacturers are - Novozymes India, Bangalore, Biocon India Ltd, Bangalore, Advanced Biochemicals, Ahemdabad, and Maps India, Ahemdabad. Novozymes was the market leader in this segment during 2006-2007, with total sales of Rs. $1,000 \mathrm{~m}$. Biocon and Advanced Biochemicals were the other major players with sales of Rs. 950 and $693 \mathrm{~m}$, respectively. ${ }^{4}$ Novozymes, Advanced Enzymes Technologies and Zytex have registered over 20 per cent growth in 2006-2007 against the previous year. Rossari registered over 60 per cent growth while Biocon registered 12 per cent growth over the previous year's sales revenue. The total revenue generated by the top five Indian enzyme manufacturers is shown in Table 5.

Currently, Novozyme is leading all the industrial enzyme manufacturers in India. For the first time, Novozymes is setting up a new $\mathrm{R} \& \mathrm{D}$ laboratory in Bangalore, India. The new facility will initially focus on optimising enzyme properties. It is expected to be fully operational from mid-2008.

Biocon India Ltd., Bangalore, is an integrated leading enzyme biotechnology company in India that has gained many accolades worldwide for its strong R\&Dbased deliverables towards product specificity 
Table 3: Major industrial enzymes and their applications

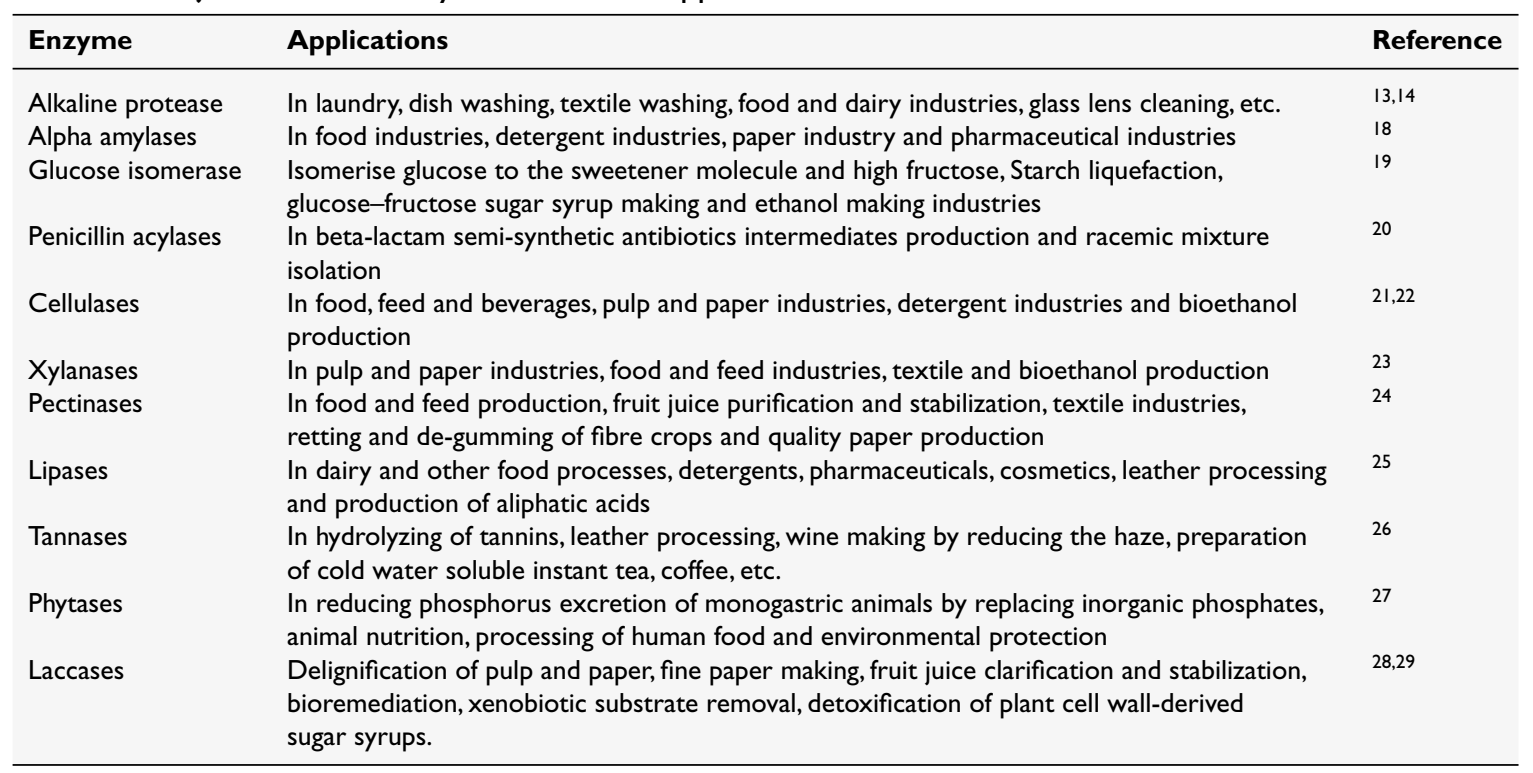

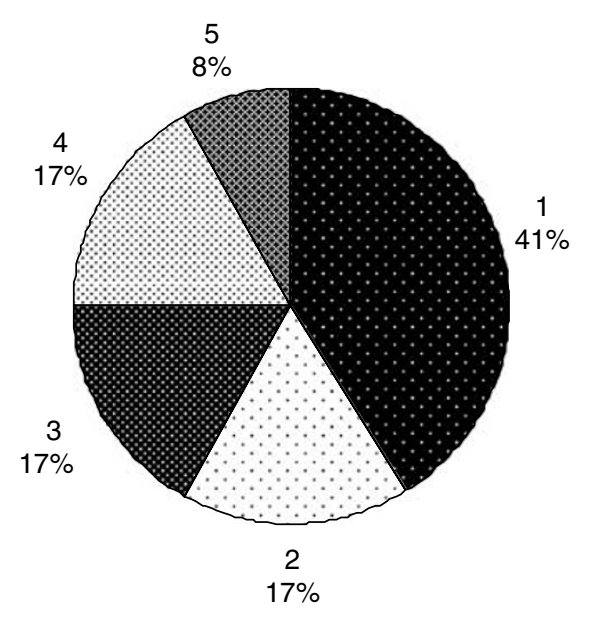

Figure I: World sales of industrial enzyme: (I) Pharmaceuticals, (2) Food and feed, (3) Detergent manufacturing, (4) Leather and paper and (5) Textile processing (Source: Biospectrum, March, 2006 (www.biospectrumindia.com))

with high output and better reproducibility. The company has a diversified product range from microbial-derived enzymes to generic bulk $\operatorname{drug}(\mathrm{s}) /$ medicine(s). The company is, however, now focusing more on biopharmaceuticals and is keen to develop some oral drug formulations for insulin and rheumatoid arthritis. According to a very recent report, the company is divesting its industrial enzyme business for Rs 4,670m to Novozymes. ${ }^{31}$

Advanced Biochemicals Ltd., Pune, has played a key role in the development of the enzyme business in India. The company is

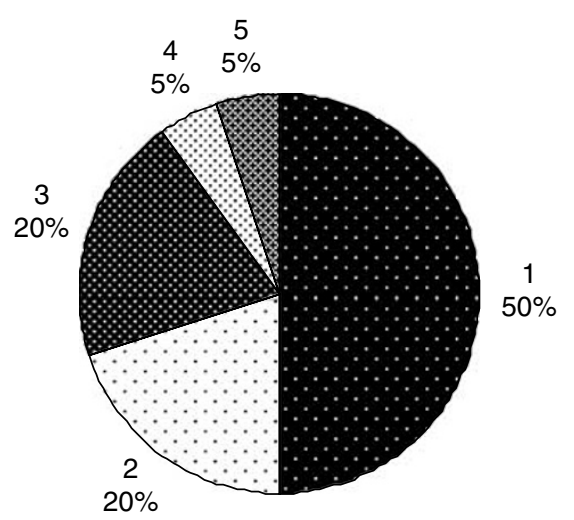

Figure 2: Indian scenario of industrial enzyme demands: (I) Pharmaceuticals, (2) Detergent manufacturing, (3) Textile processing, (4) Food and feed and (5) Leather and paper (Source: Biospectrum ${ }^{4}$ )

dedicated to the production of different microbial enzymes used in pharmaceuticals, neutraceuticals, textiles and distillation. The strong R\&D setup of the company prevailed to launch new novel enzymes with greater efficiency, less specificity and fast conversion rates with high reproducibility. The company is engaged mainly in the production of alpha-acetolactate decarboxylase, alpha amylase cellulase and alkaline protease. The company is setting up a manufacturing facility at Indore with an investment of Rs $150 \mathrm{~m}$. The company has set aside another Rs $350 \mathrm{~m}$ for its expansion. 
Table 4: Estimated enzyme consumption in various application sectors in India

\begin{tabular}{lc}
\hline Sector & Rs. (millions) \\
\hline Textile & 560 \\
Leather & 210 \\
Pharmaceuticals & 460 \\
Animal feed & 150 \\
Starch food and beverages & 210 \\
Detergents & 280 \\
Export & 310 \\
Research and diagnostics & 160 \\
Others & 470 \\
& \\
Total & 2,810 \\
\hline
\end{tabular}

Source: Biospectrum. ${ }^{4}$

Table 5: Top five Indian enzymes manufacturers (on the basis of revenue generated in 2006-2007)

\begin{tabular}{lc}
\hline Company & Revenue (Rs. millions) \\
\hline Novozyme & 1,000 \\
Biocon & 950 \\
Advanced Biochemicals & 693 \\
Rossari Biotech & 660 \\
Zytex & 150 \\
Others & 497 \\
& \\
Total Bio-industries & 3,950 \\
\hline
\end{tabular}

Source: Biospectrum, March, 2006 (www.biospectrumindia.com).

Maps India Ltd., Ahmedabad, has produced microbial-derived industrial enzymes since 1975. Their main products are palkoenzyme (alpha amylase) and palkobate (alkaline protease). The company has a strong marketing strategy to capture the domestic users as well as the foreign market.

Mumbai-based Rossari Biotech Ltd. is offering the enzyme solutions for textile auxiliaries. The company has, however, also recently ventured into newer areas like food, feed and paper starch-based enzymes.

Fermenta Biotech Ltd., Kullu, Himachal Pradesh, has been a pioneer in penicillin acylase production to meet the requirement of pharma companies for the production of beta-lactam antibiotics in India. This company is now focussed on other enzymes such as- Fermase OX 1500, Fermase PA 1500 and enantio-selective enzymes like the $\mathrm{R}$ - oxynitrilase enzyme, which is used in the preparation of high-value optically active intermediates.
Kopran Drugs Ltd., Mumbai, manufactures semi-synthetic penicillins and is among the world's highest producers of amoxycillin. The company also makes penicillin acylase for its own requirements to synthesise beta-lactam antibiotics.

Concord Biotech Ltd., Ahmedabad, is also involved in the production of penicillin acylase and other hypolipaemic products such as lovastatin, pravastatin, simvastatin, etc. The company's main product is penicillin acylase and has exported the enzyme to China and European countries since 2000.

Dalas Biotech Ltd., Bhiwadi, Rajasthan, has played a key role in the fulfilment of penicillin acylase supply to beta-lactam antibiotic manufacturers. The company is also looking for the production of glutaryl-7ACA acylase and D-amino acid oxidase, which play a key role in the biotransformation of cephalosporins into 7-amino cephalosporanic acid and glutamic acid.

Osten Enzyme India Pvt. Ltd., Chennai, manufactures, supplies and exports enzymemediated oil, bioadditives commonly used in refineries, industries and automobiles in India and abroad for pollution control, savings on fuel oil and environment protection.

Hyderabad-based Celestial Labs Ltd. has started enzyme production after establishing its state-of-art production facility at Shameerpet Industrial area, Andhra Pradesh. The company has selected today's two most common industrially important enzymes, alkaline protease and alpha amylase, for their production at the envisaged capacity of $20 \mathrm{KL}$ fermenter scale. The company has a technical tie-up with Institute of Microbial Technology (IMT), Chandigarh, one of the most reputed and premier research organisations in the country.

In India, IMT, Chandigarh, has standardised cost-effective, value-added and eco-friendly production technology for the alkaline protease and alpha amylase using submerged fermentation. Another alkaline protease preparation has been developed by Central Leather Research Institute, Chennai, under the trade name Clarizyme. ${ }^{32}$ In the country, considerable research work on Penicillin G acylase has been carried out at National Chemical Laboratory (NCL), Pune, Hindustan 
Table 6: Potential enzyme distributors/suppliers in India

\begin{tabular}{|c|c|c|}
\hline Distributors/suppliers & Business type & Products offered \\
\hline Texnzymes India, Mumbai, Maharashtra & Manufacturers & Textile auxiliaries and enzymes \\
\hline Americos Industries Inc., Ahmedabad, Gujarat & Manufacturers And exporters & Textile auxiliaries and enzymes \\
\hline Ruchi Biochemicals, Mumbai, Maharastra & Manufacturers and suppliers & Biofertilizers and industrial enzymes \\
\hline Indian Textile Auxiliary Co., Bangalore, Karnataka & Manufacturers and exporters & $\begin{array}{l}\text { Textile auxiliaries, enzymes, leather } \\
\text { auxiliaries, leather enzymes, etc. }\end{array}$ \\
\hline Zytex India Private Limited Mumbai, Maharashtra & Manufacturers and exporters & Industrial enzymes \\
\hline Naruveli Ventures Chennai, Tamil Nadu & Dealers & $\begin{array}{l}\text { Industrial enzymes, microbial products and } \\
\text { biofertilizers }\end{array}$ \\
\hline Enzyme India Private Limited, Chennai,Tamil Nadu & Manufacturers and exporters & $\begin{array}{l}\text { Enzymes for agro, bio-feed, food, detergent } \\
\text { and textiles }\end{array}$ \\
\hline $\begin{array}{l}\text { Prasanthi Leather Chem Private Limited, Kolkata, } \\
\text { West Bengal }\end{array}$ & $\begin{array}{l}\text { Wholesale suppliers/Distributor } \\
\text { sellers }\end{array}$ & Enzymes and fat liquors, etc. \\
\hline Biomax, Thane, Maharashtra & Manufacturers & Biofertilzers, soil modifiers and enzymes \\
\hline $\begin{array}{l}\text { Genotex International Private Limited, Hyderabad, } \\
\text { Andhra Pradesh }\end{array}$ & Manufacturers and exporters & $\begin{array}{l}\text { Industrial enzymes, Aloe vera juice and } \\
\text { patented peptides }\end{array}$ \\
\hline Protos Trading Private Limited, New Delhi & Importers/buyers & Textile enzymes \\
\hline
\end{tabular}

Antibiotics Ltd., Pimpri, Pune, and Madurai Kamraj University, Madurai. Glucose isomerase, phytase, laccases and lipases have been the major thrust areas at University of Delhi, South Campus, New Delhi. Central Leather Research Institute (CLRI), Chennai, has mainly targeted tannases. Xylanases have been the focus of research at Thapar Institute of Engineering and Technology, Patiala. Cellulases have been focused upon at IIT (Indian Institute of Technology), Delhi. Alkaline pectinase has been the area of research at Microbiology Department, Panjab University, Chandigarh. Apart from the abovementioned research centres, other laboratories are also engaged in enzyme research and are doing well. A description of the details of each research centre is beyond of the scope of this paper.

\section{ENZYME DISTRIBUTORS/ SUPPLIERS IN INDIA}

Today, the Indian biotech sector has attained critical mass in manufacturing and research services. Indian biotechnology is now poised to leverage its scientific skills and technical experiences to make a global impact on a strong innovation-led platform. The technological capability of a firm to produce some products is only a part of the requirement for the commercial success of the business. Apart from technological capabilities, the firm must be able to position its product in the market. The market, thus, serves as the link between consumers' needs and the pattern of industrial response. ${ }^{33}$ Table 6 shows the potential enzyme distributors/suppliers in India. There are, however, several enzyme distributors in the country, but here we briefly summarise the main and potential ones. Their role is highly specific in upgrading the successful commercialisation status of industrial enzymes. The role of the direct distributors/supplier is to promptly supply enzymes to the end users.

\section{FUTURE SCENARIO OF INDUSTRIAL ENZYMES IN INDIA}

With the advent of biotechnology, there has been a growing interest in and demand for enzymes with novel properties. Enzymes from marine microorganisms have unique properties and have proven their industrial applications. ${ }^{34}$ Other special enzymes are thermo-tolerant enzymes, which have shown enhanced stability even under highly stringent conditions. These enzymes provide unique advantages like greater stability during the substrate conversion, which results in more 
conversion cycles, thus saving energy and time. ${ }^{35}$ Genetic engineering is of central importance for the development of novel genetically modified or 'designer' enzymes. India is still fulfilling its enzyme demand by importing to the tune of 70 per cent from US, Canada and China. Looking into the increased demand of enzymes in the future, a nationwide production development programme needs to be initiated with support from the government and private sector funds. Future achievements will include a much greater appreciation of structure-function relationships in enzymes, screening of novel and high enzyme titre-yielding strains, improvement in production yields adopting statistical approaches and improvement in downstream recovery of enzymes, etc.

\section{CONCLUSION}

Enzymes can be considered as green chemicals; they have very wide applications and can be referred to as household commodities owing to their role in today's human activities. The government of India through the Department of Biotechnology (DBT), the Department of science and Technology (DST) and the Council of Scientific and Industrial Research (CSIR) has been considerate to the bioindustrial sector, and funding projects related to industrial enzymes. This will help the industry grow, launch new products and compete with global players.

Enzymes have a significant role in the production of biofuels- the fuels of future. Cellulases, xylanases and amylases act on cellulosics and starchy substrates to yield a cocktail of carbohydrates that can be converted into motor fuel (ethanol) after fermentation with appropriate microorganisms.

India still imports 70 per cent of its enzyme requirements from the US, Canada and China. If more research and entrepreneurship attention is focused on in-house production of enzymes, it will create more employment and income, which can expedite the new ways of saving the foreign exchange reserves.

The bioindustrial sector, which mainly comprises enzyme production companies, is estimated to be Rs. 3,200m in 2004-2005 and has an influential impact on the country's economic growth. Among the Indian enzyme manufacturers, Novozymes ranks top by generating a revenue of Rs. $1,000 \mathrm{~m}$ followed by Biocon (Rs. 950m) and Advanced biochemicals (Rs. 693m) during the year 2006-2007.

To summarise, industrial enzymes have played a significant role in today's commercial status of biotechnology in India. The future will witness more and novel applications of microbial enzymes in far greater areas than what we could anticipate today.

\section{Acknowledgments}

We thank Dr A.N. Singh, Managing Director, Celestial Labs Ltd, Hyderabad, for providing the necessary facilities for data compilation, and Dr Neil Henderson, Palgrave Macmillan and Mrs. Nirmala Rudravaram for their insightful suggestions regarding the manuscript content.

\section{References}

1. The Times of India, 15th June 2007 (www. timesofindia.com).

2. www.bloomberg.com.

3. Mani, S. (2006). Growth of new technology-based industries in India, the contrasting experiences of Biotechnology and information technology industries. Int. J. Technol. Global. 2, 200-216.

4. Industrial Enzymes, Biospectrum, 2005 http:// www.biospectrumindia.com/.

5. Ernst \& Young (2005). Annual Global Biotechnology Report - Beyond Borders, Ernst \& Young, Ireland.

6. Company News, Focus on Catalysts, 2007.

7. Buchholz, K. \& Poulson, P. B. (2000). Overview of history of applied biocatalysis, in Straathof, A.J.J. and Adlercreutz, P. (eds.), Applied Biocatalysis, Harwood Academic Publishers, Amsterdam, pp. 1-15.

8. Sijbesma, F., DSM, 2006 (www.dsm.com).

9. Kirk, O., Borchert, T.V. \& Fuglsang, C. C. (2002). Industrial enzyme applications. Curr. Opin. Biotechnol. 13, 345-351.

10. Chand, S. \& Mishra, P. (2003). Research and Application of Microbial Enzymes - India's Contribution Advances in Biochemical Engineering/Biotechnology Springer Berlin/ Heidelberg, Vol. 85, Biotechnology in India, 95-124.

11. Bailey, J. E. \& Ollis, D. F. (1997). Biochemical Engineering Fundamentals. TP 248. 3. B34.

12. Payen, A., Persoz, J. F. (1833). 'Mémoire sur la diastase, les principaux produits de ses réactions, et leurs Applications aux arts industriels', Ann. Chim. Phys., 2me Série 53, pp. 73-92. 
13. Maurer, K. H. (2004). Detergent proteases. Curr. Opin. Biotechnol. 15, 330-334.

14. Gupta, R., Beg, Q. K. \& Lorentz, P. (2002). Bacterial alkaline proteases: molecular approaches and industrial application. Appl. Microbiol. Biotechnol. 59, 15-32.

15. Zlinski, T. \& Aldmann, H. (1997). Cross-linked enzyme crystals (clecs): Efficient and stable biocatalysts for preparative organic chemistry. Angew. Chem., Int. ed. Engl. 36, 22-724.

16. Bruggink, A., Roos, E. C. \& De Vroom, E. (1998). Penicillin acylase in the industrial production of beta-lactam antibiotics. Org. Proc. Res. Dev. 2, 128-133.

17. Herrera, S. (2004). Industrial biotechnology- a chance at redemption. Nat. Biotechnol. 22, 671-675.

18. Sivaramakrishnan, S., Gangadharan, D., Nampoothiri, K. M., Soccol, C. R. \& Pandey, A. (2006). Alpha-amylase from microbial sources-An overview on recent developments. Food Technol. Biotechnol. 44(2), 173-184.

19. Bhosale, S. H., Rao, M. B. \& Deshpande, V.V. (1996). Molecular and industrial aspects of glucose isomerase. Microbiol. Mol. Biol. Rev. 60, 280-300.

20. Rajendhran, J., Krishnakumar, V. \& Gunasekaran, P. (2002). Optimization of a fermentation medium for the production of Penicillin G acylase from Bacillus sp. Lett. Appl. Microbiol. 35, 523-527.

21. Chinn, M. S., Nokes, S. E. \& Strobel, H. J. (2001). Bacterial cellulases: A review: Paper number 017017. Am. Soc. Agr. Biol. Eng. Ann. Meet.

22. Chandel, A. K., Chan, E. S., Rudravaram, R., Narasu, M. L., Rao, L. V. \& Ravindra, P. (2007a). Economics and environmental impact of bioethanol production technologies: An appraisal. Biotechnol. Mol. Biol. Rev. 2, 14-32.

23. Bajpai, P. (1999). Applications of enzymes in the pulp and paper industry. Biotechnol. Prog. 15, 147-157.
24. Hoondal, G., Tiwari, R., Tewari, R., Dahiya, N. \& Beg, Q. (2002). Microbial alkaline pectinases and their industrial applications: A review. Appl. Microbiol. Biotechnol. 59, 409-418.

25. Seitz, E. W. (1974). Industrial applications of microbial lipases: A review. J. Am. Oil Chem. Soc. 51, 12-16.

26. Aguilar, C. N. \& Sanchez, G. G. (2001). Review: Sources, properties, applications and potential uses of tannin Acyl Hydrolase. Food Sci. Technol. Int. 7, 373-382.

27. Haefner, S., Knietsch, A., Scholten, E., Braun, J., Lohscheidt, M. \& Zelder, O. (2005). Biotechnological production and applications of phytases. Appl. Microbiol. Biotechnol. 68(5), 588-597.

28. Couto, S. R. \& Herrera, T. J. L. (2006). Lacasses in the textile industry. Biotechnol. Mol. Biol. Rev. 1(4), $115-120$.

29. Chandel, A. K., Kapoor, R. K., Singh, A. K. \& Kuhad, R. C. (2007b). Detoxification of sugarcane bagasse hydrolysate improves ethanol production by Candida shehatae NCIM 3501. Biores. Technol. 98, 1947-1950.

30. Association of Biotechnology Led Enterprise (ABLE, 2005).

31. The Times of India, 19 July, 2007 (www. timesofindia.com).

32. Kumar, C. G., Ph D Thesis, National Dairy Research Institute (Deemed University), Karnal, 1997.

33. Negi,Y. S. \& Tewari, S. C. (1999). Economics of fermented products, in Joshi, V.K. and Pandey, A (eds.), Biotechnology: Food Fermentation (Vol. 1), Educational Publishers and Distributors, Kerala, India.

34. Chandrasekaran, M. (1997). Industrial enzymes from marine microorganisms: The Indian scenario. J. Mar. Biotechnol. 5, 86-89.

35. Haki, G. D. \& Rakshit, S. K. (2003). Developments in industrially important thermostable enzymes: A review. Biores. Technol. 89, 17-34. 